\title{
Effect of fatty acid content in the diet on lipid profile in HIV-infected patients treated with antiretroviral drugs
}

\author{
Agata Jackiewicz ${ }^{1}$, Marcin Czarnecki², Anna Przeliorz-Pyszczek ${ }^{1}$, Brygida Knysz ${ }^{2}$ \\ ${ }^{1}$ Division of Dietetics, Wroclaw Medical University, Poland \\ ${ }^{2}$ Department of Infectious Diseases, Liver Diseases and Acquired Immune Deficiences, Wroclaw Medical University, Poland
}

\begin{abstract}
Introduction: Metabolic syndrome has become an important issue affecting the long-term prognosis of human immunodeficiency virus (HIV) patients in the context of cardiovascular disease. The aim of the study was to determine whether the amount and quality of dietary fats consumed had an effect on total, low-density lipoprotein (LDL) and high-density lipoprotein (HDL) cholesterol and triglycerides (TG), the glycemic load had an effect on TG concentration, and quality of consumed fats had an impact on cardiovascular risk.

Material and methods: $80 \mathrm{HIV}(+)$ patients treated with protease inhibitors (PIs) and nucleoside reverse transcriptase inhibitors (NRTIs) were involved in the study. Information on the diet and eating habits was collected by 24-hour dietary recall and a questionnaire prepared by the researchers. The analysis of nutritional value of the diet was made using the Food Processor diet program.

Results: A statistically significant correlation between saturated fatty acids (SFA) diet content and a negative correlation between the content of polyunsaturated fatty acids (PUFA) and LDL cholesterol levels was observed. A positive correlation between omega 6 (n6)/omega 3 (n3) fatty acid ratio, and negative between glycemic load of diet and total cholesterol levels were found. The 10 -year risk of CD was: high $3.75 \%$, medium $12.5 \%$, low $83.75 \%$. Smoking was the most potent risk factor.

Conclusions: The diets of the study group of $\mathrm{HIV}(+)$ patients should be properly balanced and require modifications of many nutritional habits. The effectiveness of treatment of HIV-infected patients may be strongly influenced by dietary intervention. Therefore it seems advisable to include a dietitian in the group of specialists who take care of these patients.
\end{abstract}

HIV AIDS Rev 2019; 18, 1: 25-32

DOI: https://doi.org/10.5114/hivar.2019.84124

Key words: diet, HIV, lipid profile, antiretroviral therapy, cardiovascular disease risk.

\section{Introduction}

Introduction of highly active antiretroviral therapy (HAART) allowed the life expectancy of human immunodeficiency virus (HIV)-positive people to be prolonged [1]. There has also been a decrease in mortality and morbidity associated with immunodeficiency induced by HIV [2].

As in the general population, the clinical problem has become, among others, metabolic disorders and related cardiovascular diseases (CVD) [1, 3].

Metabolic syndrome has become an important issue affecting the long-term prognosis of $\mathrm{HIV}(+)$ patients in the context of CVD [4].

Article history:

Received: 27.06.2018

Received in revised form: 04.12 .2018

Accepted: 05.12.2018

Available online: 15.03.2019
International Journal of HIV-Related Problems

HIV \& AIDS Re vi e w 
Increase of triglycerides (TG), total cholesterol (TC) and low-density lipoprotein cholesterol (LDL-C) levels as well as the decrease of high-density lipoprotein cholesterol (HDL-C) levels are well-known problems associated with the use of combined antiretroviral therapy (cART) $[1,5]$. Studies of both Polish and foreign authors showed disturbances in the lipid profile, and values were dependent on the class of antiretroviral drugs used $[1,6,7]$. Similarly as in the case of hypercholesterolemia, the severity of hypertriglyceridemia depends on the class of antiretroviral drugs used. Hypertriglyceridemia's prevalence may reach even $60 \%$ with the combination of nucleoside reverse transcriptase inhibitors (NRTIs) with protease inhibitors (PIs) [8].

An important issue from the point of view of dyslipidemia prevention and its treatment in the context of CVD is the quality of consumed fat, as demonstrated in the Seven Countries Study $[9,10]$. It is worth noting that saturated fatty acids (SFA) intake causes a significant increase in the TC and LDL-C levels in the blood [8].

Monounsaturated and polyunsaturated fatty acids (monounsaturated fatty acid - MUFA, polyunsaturated fatty acid - PUFA) have an LDL-lowering effect. In addition, MUFA causes an increase in HDL-C concentration [11, 12]. Polyunsaturated fatty acids, in particular long-chain forms, and the omega 6 to omega $3(n 6 / n 3)$ ratio of $4-5: 1$ [13] have anti-atherosclerotic, anti-inflammatory and anti-aggregating effects [14], favoring protection against the occurrence of diseases associated with the cardiovascular system [15-17].

In the context of reducing the risk of CVD the use of the Mediterranean diet is discussed $[14,16]$. Numerous studies suggest that the optimal ratio of n-6/n-3 fatty acids can be achieved thanks to the Mediterranean diet. It is believed that the increased ratio of these fatty acids promotes the development of CVD, cancer, and inflammatory and autoimmune diseases [13].

Non-pharmacological treatment including nutritional support could promote better control of lipid levels, leading to reduced CVD risk, reduce the need for additional pharmacotherapy and also avoid drug interactions or other side effects $[4,18]$.

The aim of the study was to determine whether the amount and quality of dietary fats consumed had an effect on TC, LDL-C and HDL-C and TG, the glycemic load had an effect on TG concentration, and the quality of consumed fats had an impact on cardiovascular risk calculated using the Framingham scale.

\section{Material and methods}

\section{Material}

The study included 80 HIV-positive patients aged 18 70 years who were on stable NRTIs together with PIs based antiretroviral therapy for at least 12 months after the onset of treatment. The patients were selected from the Prophylactic and Infectious Diseases Center and Addiction Therapy in Wroclaw, Poland. Acquired immune deficiency syndrome
(AIDS) was an exclusion criterion. Patients were informed about the purpose of the study and its voluntary and anonymous nature, and signed informed consent to participate in the study.

\section{Clinical evaluation}

All patients were evaluated during their visit to a dietitian. During the visit age and gender data were collected along with anthropometric measurements. In order to assess the patients' nutritional habits, 24-hour dietary recall and the author's questionnaire which asked about levels of physical activity, smoking, the amount and type of meals consumed, the culinary techniques used and the frequency of consumption of the food groups were used. In addition, information on blood pressure, lipid profile, medications used in its treatment (statins, fibrates), hypoglycemic medications, and hypertension treatment use was gathered from existing medical records.

\section{Methods}

\section{Laboratory tests}

The results of laboratory tests were obtained from routine examinations of patients under constant medical supervision. TC, LDL-C, HDL-C and blood TG levels were taken into account.

\section{Anthropometric measurements}

The anthropometric measurements included body weight, height and hip/waist circumference. Waist and hip circumferences were measured using a standard measuring tape to the nearest $1 \mathrm{~cm}$. The waist circumference was measured halfway between the upper hip bone crest and the lower rib curve. The hip circumference was measured at the widest point below the hip plates, at the bulge of the buttocks [19]. A proper result according to the International Diabetes Federation guidelines was defined as waist circumference $<94 \mathrm{~cm}$ for men and $<80 \mathrm{~cm}$ for women [20].

The WHR (waist-hip ratio) was used to determine body type, the value of which depends on the distribution of adipose tissue in the body. The WHR was calculated using the obtained waist and hip circumferences. Values $<1.0$ in men and $<0.8$ in women indicate gynoid obesity, while values $\geq 1.0$ in men and $\geq 0.8$ in women indicate the presence of android (abdominal) obesity [19].

Body mass index (BMI) was used to classify body mass. Its values were referenced to World Health Organization (WHO) BMI ranges [21].

\section{Cardiovascular risk assessment based on the Framingham scale}

According to the recommendations from the Polish AIDS Society (PTN AIDS), the Framingham scale was used to assess cardiovascular risk of HIV-infected patients [21]. 
Ten-year cardiovascular risk was assessed on the basis of the sum of the points awarded. Table 1 presents the number of points awarded during the assessment based on the Framingham scale. Low risk of cardiovascular events was found to be low $<10 \%$, moderate $10-20 \%$, and high $>20 \%$ [22]. Estimates of 10-year risk for coronary heart disease are presented in Table 2.

\section{Evaluation of intake of particular nutrients}

Nutrition data were collected using a 24-hour dietary recall from the three days preceding the study, two weekdays and one weekend, and then entered in the ESHA Food Processor $[23,24]$. The data obtained were compared with HIV norms, which according to the WHO report do not differ from those of the general population $[25,26]$.

\section{Statistical analysis}

For the purpose of the study collected material was uploaded to a specially developed database in Excel 2007. All calculations were made using the statistical package SPSS Statistica 21.0.

The results were analyzed descriptively and statistically. The $\chi^{2}$ test was used to examine the statistical relationship between the analyzed features. The results obtained were statistically analyzed by the $\chi^{2}$ test for independent trials. $5 \%$ risk of error inference was assumed. The probability value $p<0.05$ was considered statistically significant.

\section{Results}

Data were collected from $80 \mathrm{HIV}$-infected patients aged 24-67 years $(40.6 \pm 8.8)$ on NRTIs + PIs. The characteristics of the study group are presented in Table 3 . The mean body mass index among patients was $24.04 \mathrm{~kg} / \mathrm{m}^{2}\left(18.2-45.4 \mathrm{~kg} / \mathrm{m}^{2}\right)$; $33.8 \%$ of subjects had abnormal BMI exceeding $25 \mathrm{~kg} / \mathrm{m}^{2}$. The mean WHR in the study population was 0.91 , with 0.81 for women and 0.94 for men. In all 6 patients with BMI more than $30 \mathrm{~kg} / \mathrm{m}^{2}$ android obesity was reported.

Mean blood pressure values in the study group were $128.35( \pm 21.42) / 82.56( \pm 10.80) \mathrm{mmHg}$.

Two of the 80 patients used lipid-lowering drugs, one hypoglycemic agent, and 16 hypotensive agents. The triglyceride values of patients treated with fibrates did not exceed
Table 1. Estimate of 10-year risk for coronary heart disease Framingham point scores

\begin{tabular}{|c|c|c|c|c|}
\hline \multicolumn{2}{|c|}{ Risk } & $n$ & \multicolumn{2}{|c|}{$\%$} \\
\hline$<1 \%$ & \multirow{8}{*}{ Low } & 18 & 22.50 & \multirow{8}{*}{83.75} \\
\hline $1 \%$ & & 18 & 22.50 & \\
\hline $2 \%$ & & 9 & 11.25 & \\
\hline $3 \%$ & & 3 & 3.75 & \\
\hline $4 \%$ & & 5 & 6.25 & \\
\hline $5 \%$ & & 5 & 6.25 & \\
\hline $6 \%$ & & 8 & 10.00 & \\
\hline $8 \%$ & & 1 & 1.25 & \\
\hline $10 \%$ & \multirow{4}{*}{ Medium } & 3 & 3.75 & \multirow{4}{*}{12.50} \\
\hline $11 \%$ & & 2 & 2.50 & \\
\hline $12 \%$ & & 4 & 5.00 & \\
\hline $16 \%$ & & 1 & 1.25 & \\
\hline $20 \%$ & \multirow{2}{*}{ High } & 2 & 2.50 & \multirow{2}{*}{3.75} \\
\hline $30 \%$ & & 1 & 1.25 & \\
\hline
\end{tabular}

$124 \mathrm{mg} / \mathrm{dl}$. In contrast, the TG level of a patient using metformin was $160 \mathrm{mg} / \mathrm{dl}$. The diet of all three patients was characterized by high glycemic loads, saturated fatty acid content and $\mathrm{n} 6 / \mathrm{n} 3$ ratio, as well as low physical activity.

\section{Characteristics of lipid profile}

The mean TC level in the study group was $184.39 \mathrm{mg} / \mathrm{dl}$, LDL-C $103.75 \mathrm{mg} / \mathrm{dl}$, HDL-C $52.30 \mathrm{mg} / \mathrm{dl}$ and TG $146.67 \mathrm{mg} / \mathrm{dl}$. Abnormal TC values $(\geq 190 \mathrm{mg} / \mathrm{dl}$ ) were reported in 32 patients, LDL-C $(\geq 115 \mathrm{mg} / \mathrm{dl})$ in 24 patients, HDL-C (women $<50 \mathrm{mg} / \mathrm{dl}$, men $<40 \mathrm{mg} / \mathrm{dl}$ ) in 27 patients and TG $(\geq 150 \mathrm{mg} / \mathrm{dl}$ ) among 31 patients. The characteristics of the lipid profile of the group are presented in Table 4.

\section{Nutritional value of the diet}

The caloric intake of the study population was $2449.01 \pm$ 693.05 calories per day. In the study group the mean diet energy profile was $46.81 \pm 7.37 \%$ from carbohydrates, $14.58 \pm$ $3.34 \%$ from proteins, and $36.97 \pm 7.60 \%$ from fat. The amount of SFA in the diet was $13.30 \pm 3.80 \%$ on average, monounsatu-

Table 2. Characteristics of the number of points awarded to assess the 10-year risk of cardiovascular diseases by the Framingham scale

\begin{tabular}{l|c|c|c|c|c}
\hline Factor & Age & Cigarette smoking & HDL-cholesterol & Total cholesterol & Systolic pressure \\
\hline Awarded points & -1.33 & 301.00 & 47.00 & 272.00 & 44.00 \\
\hline Mean & -1.66 & 3.76 & 0.59 & 3.40 & 0.55 \\
\hline SD & 5.65 & 3.58 & 1.21 & 2.86 & 0.84 \\
\hline Median & -3.00 & 4.00 & 1.00 & 4.00 & 0.00 \\
\hline Minimum & -9.00 & 0.00 & -1.00 & 0.00 & 0.00 \\
\hline Maximum & 12.00 & 9.00 & 2.00 & 11.00 & 3.00 \\
\hline
\end{tabular}


Table 3. Characteristics of the group of patients $(n=80)$

\begin{tabular}{l|c|c|c|c|c}
\hline Factor & Mean & SD & Minimum & Maximum & Median \\
\hline Age & 40.60 & 8.80 & 24.00 & 67.00 & 39.00 \\
\hline Height $(\mathrm{m})$ & 1.73 & 0.72 & 1.58 & 1.88 & 1.74 \\
\hline BMI $\left(\mathrm{kg} / \mathrm{m}^{2}\right)$ & 24.04 & 4.47 & 18.20 & 45.40 & 22.90 \\
\hline Weight $(\mathrm{kg})$ & 72.18 & 14.61 & 49.00 & 125.00 & 70.00 \\
\hline Waist circumference $(\mathrm{cm})$ & 87.52 & 12.13 & 64.00 & 122.00 & 85.00 \\
\hline Hip circumference $(\mathrm{cm})$ & 96.45 & 8.30 & 85.00 & 145.00 & 95.00 \\
\hline WHR & 0.91 & 0.09 & 0.70 & 1.15 & 0.89 \\
\hline
\end{tabular}

Table 4. Characteristics of the lipid profile of the group of patients $(n=80)$

\begin{tabular}{l|c|c|c|c}
\hline Parameter & Total cholesterol & HDL & LDL & TG \\
\hline Mean & 184.39 & 52.30 & 103.75 & 146.77 \\
\hline SD & 43.89 & 20.21 & 40.61 & 64.39 \\
\hline Minimum & 70.00 & 24.00 & 14.00 & 47.00 \\
\hline Maximum & 303.00 & 119.00 & 196.00 & 343.00 \\
\hline Median & 177.00 & 44.00 & 98.00 & 132.00 \\
\hline
\end{tabular}

Table 5. Content of saturated, monounsaturated and polyunsaturated fatty acids in patients' diets $(n=80)$

\begin{tabular}{l|c|c|c|c|c}
\hline Parameter & Mean & SD & Median & Max & Min \\
\hline SFA (g) & 37.87 & 17.05 & 34.45 & 92.85 & 7.17 \\
\hline SFA \% & 13.20 & 3.80 & 12.81 & 22.31 & 3.31 \\
\hline MUFA (g) & 40.65 & 15.85 & 39.22 & 84.30 & 7.40 \\
\hline MUFA \% & 14.31 & 3.45 & 14.20 & 21.85 & 3.42 \\
\hline PUFA (g) & 19.44 & 9.72 & 17.51 & 48.39 & 2.74 \\
\hline PUFA \% & 6.91 & 2.87 & 6.23 & 15.77 & 1.27 \\
\hline
\end{tabular}

rated fatty acids accounted for $14.31 \pm 3.45 \%$ while polyunsaturated fatty acids $6.91 \pm 2.87 \%$ of dietary energy.

In evaluated diets, the amount of n- 6 consumed exceeded the norm twice and the norm for $n-3$ acid intake was fulfilled. Table 5 presents the content of SFA, MUFA and PUFA in patients' diets. The polyunsaturated fatty acids comprised $16.84 \pm 8.97 \mathrm{~g}$ omega- 6 fatty acid and $2.39 \pm 1.50 \mathrm{~g}$ omega- 3 fatty acids. The characteristics of polyunsaturated fatty acids in patients' diets are presented in Table 6.

\section{Characteristics of lifestyle}

About $58.75 \%$ answered the questionnaire positively about smoking, while $41.75 \%$ did not report smoking in the last year. Another question was about the level of physical activity. Only 19 patients $(23.8 \%)$ reported fulfilling the recommended amount of physical activity of 30-60 minutes each day [27].

\section{Cardiovascular risk calculated by Framingham scale}

The 10-year low risk of cardiovascular disease applied to $83.75 \%$, medium $12.50 \%$, and high $3.75 \%$ of the study pop-

Table 6. Characteristics of polyunsaturated fatty acids in patients' diets $(n=80)$

\begin{tabular}{l|c|c|c|c|c}
\hline Omega-6 fatty acid & Mean & SD & Median & Max & Min \\
\hline Parameter & 16.69 & 8.86 & 15.12 & 43.72 & 2.48 \\
\hline Linoleic & 0.15 & 0.11 & 0.12 & 0.60 & 0.02 \\
\hline Arachidonic & 16.84 & 8.97 & 15.24 & 44.32 & 2.50 \\
\hline The sum of omega-6 & Mean & SD & Median & Max & Min \\
\hline Omega-3 fatty acid & 2.28 & 1.29 & 2.12 & 9.72 & 0.14 \\
\hline Parameter & 0.08 & 0.14 & 0.01 & 0.63 & 0.00 \\
\hline Alpha-linolenic & 0.03 & 0.07 & 0.01 & 0.40 & 0.00 \\
\hline EPA & 2.39 & 1.50 & 2.14 & 10.75 & 0.14 \\
\hline DHA & \multicolumn{7}{|l|}{} \\
\hline The sum of omega-3 & Mean & SD & Median & Max & Min \\
\hline n6/n3 fatty acid ratio & 7.04 & 5.99 & 7.14 & 4.12 & 17.86 \\
\hline Parameter & \multicolumn{7}{|l|}{}
\end{tabular}


Table 7. Pearson's correlation between SFA, n6/n3 ratio and glycemic load, and lipid profile $(n=80)$ for significance level $p<0.05$

\begin{tabular}{l|c|c|c|c|c|c}
\hline \multicolumn{2}{l|}{ Parameter } & SFA\% & MUFA & PUFA\% & n6/n3 & Glycemic load \\
\hline \multirow{2}{*}{ Total cholesterol } & $r$ & 0.12 & -0.06 & 0.09 & 0.28 & 0.09 \\
\cline { 2 - 7 } & $p$ & NS & NS & NS & 0.01 & NS \\
\hline \multirow{2}{*}{ LDL cholesterol } & $r$ & 0.26 & 0.18 & -0.22 & 0.06 & -0.22 \\
\hline \multirow{2}{*}{ Triglicerydes } & $p$ & 0.04 & NS & 0.05 & NS & 0.05 \\
\hline \multirow{2}{*}{ HDL cholesterol } & $r$ & 0.02 & 0.09 & -0.04 & 0.18 & 0.10 \\
\cline { 2 - 7 } & $p$ & NS & NS & NS & NS & NS \\
\hline
\end{tabular}

ulation. During the risk assessment the most points were awarded respectively for smoking, total and HDL-C and systolic blood pressure. Young age was a factor reducing cardiovascular risk in the study group. The study showed a statistically significant relationship between the ratio of $\mathrm{n} 6 / \mathrm{n} 3$ and cardiovascular risk. Risk increased with a higher ratio of fatty acids.

\section{Effect of lipid quality on lipid profile parameters}

The analysis of the results showed a statistically significant positive correlation between the content of SFA in the diet and a negative correlation between the PUFA content and the LDL-C level. A correlation was also observed between the $\mathrm{n} 6 / \mathrm{n} 3$ ratio in the diet and the TC values. Furthermore, a statistically significant relationship was found between the glycemic load and cholesterol values in the diet. With the increase of the load, LDL-C decreased (Table 7). The analysis of the results showed no significant correlation between physical activity, fat content in diet and glycemic load and patients' BMI and WHR (Table 8). There was a statistically significant correlation between WHR and triglycerides and HDL cholesterol levels. As the WHR increased, TG values increased while HDL-C levels decreased.

\section{Discussion}

In our study on $80 \mathrm{HIV}(+)$ patients treated with PIs, abnormal values of TC were found in $40 \%$ of participants. This is reflected in the observations of others, including Polish authors [7]. In our group the proportion of patients with abnormal LDL levels was higher than in the HIV $(+)$ patients from the POLCA cohort who were not treated with ARV drugs (30\% vs. $21 \%)$. Incorrect HDL-C values were more common in our population than in the POLCA cohort (33.75\% vs. $20 \%$ ), which may be due to the use of cART [7].

Incorrect $\mathrm{TG}$ values were observed in a larger proportion of subjects in our study compared to Tsiodras et al. (38.75\% vs. $19 \%)$. This difference may be due to the lack of interview about the use of hypoglycemic drugs in the Tsiodras et al. report [28]. It was found in our study that only 2 patients
Table 8. Pearson's correlation between glycemic load, dietary fat content and level of physical activity, and BMI and WHR of patients $(n=80)$ for significance level $p<0.05$

\begin{tabular}{l|c|c|c}
\hline \multicolumn{1}{l|}{ Parameter } & BMI & WHR \\
\hline \multirow{2}{*}{ Glycemic load } & $r$ & 0.057 & 0.283 \\
\cline { 2 - 4 } & $p$ & NS & NS \\
\hline \multirow{2}{*}{ Fat content (\%) } & $r$ & 0.217 & -0.007 \\
\cline { 2 - 4 } & $p$ & NS & NS \\
\hline \multirow{2}{*}{ Physical activity } & $r$ & 0.019 & 0.033 \\
\cline { 2 - 4 } & $p$ & NS & NS \\
\hline
\end{tabular}

received fibrates and only 1 metformin, and it had no significant effect on the mean lipid profile. In addition, the Tisodras et al. study was conducted between 1993 and 1998 when the quality of the consumed products was different from those of the years 2015-2016. Nowadays, high-processed products are commonly consumed, which due to high caloric density and glycemic index can affect TG concentrations.

The analysis of patients' diets revealed many bad dietary habits leading to poorly balanced diets. Patients consumed too much meat, which is a large source of saturated fatty acids. Three quarters of the patients eat red meat often while fish, which is an important source of polyunsaturated fatty acids, is neglected in the diet by a quarter of the study population. The quality of the consumed fat can be assessed as relatively good. The vast majority of patients report the consumption of vegetable oils, the most commonly chosen being rapeseed oil and olive oil. However, it should be noted that half of the respondents use butter, a common source of SFA, in their cooking. Dairy products, which are an important source of easily digestible protein in the diet, are selected by nearly $50 \%$ in a non-recommended whole fat form. Patients consume too many sweet drinks, snacks and added sugar. They are a source of simple sugars, which should be minimized or eliminated completely from the diet as recommended by the American Heart Association [29]. In the study group almost half of the patients use techniques leading to adverse changes in nutritional values of the meals. 
According to the WHO guidelines, the diet of HIV-infected patients without AIDS should be based on proper nutrition recommendations, so proteins should represent $15 \%$, carbohydrates $50-70 \%$ and fats $20-35 \%$ of energy needs $[25,26]$. The analysis of diet composition showed that the amount of consumed fat was too high and its qualitative composition was unfavorable. In addition, in almost half of the diets the amount of fiber consumed did not meet the recommended standards.

According to the standards of nutrition for the Polish population, SFA should not exceed $10 \%$ of the energy of the diet [24]. However, according to the recommendations of the American Heart Association in 2013, individuals should reduce the consumption of SFA by up to $5-6 \%$ of energy from the diet [30]. In this study the amount of SFA exceeded twice the recommended value. We have shown that a high SFA content in the diet promotes higher LDL-C levels, whereas higher PUFA intake correlates negatively with its values. The mechanism of influence of individual fatty acids on the level of lipids has been studied [31], and numerous studies confirm the relationship between high levels of SFA and low PUFA in diets and LDL-C concentrations [32]. We did not find any correlation between the consumption of SFA and the TC reported by other investigators, which may be due to the small sample size of the study group [17].

In this study we found that the mean ratio of $\mathrm{n} 6 / \mathrm{n} 3 \mathrm{ex}-$ ceeded the recommended 4-5:1 [15]. We also found a correlation between the ratio of $\mathrm{n} 6 / \mathrm{n} 3$ in the diet and TC values. Their concentrations increased with a higher ratio of n6/ n3. No other studies have discussed the effects of the fatty acid ratio on TC. However, a low ratio of $n 6 / n 3$ is known to reduce the risk of many diseases and to reduce the risk of cardiovascular events [13,33]. Another statistically significant correlation observed in our study was between glycemic load diet and LDL-C. With the increase in glycemic load LDL -C decreased. Other studies confirm the existence of an inverse correlation [33-35]. This contradiction may be related to the previously reported negative correlation between consumption of PUFA and LDL-C level, which was not considered in the study by Li et al. [34]. It can be assumed that PUFA's effect on lowering LDL-C could have been adversely affected by higher glycemic load. The above results allow for a partial acceptance of the research hypothesis concerning the effect of the quality and amount of fat consumed on the lipid profile.

The glycemic load is positively correlated with the TG concentration and an indicator that allows one to assess the dietary load of carbohydrates [36]. Finley et al. demonstrated a positive correlation between glycemic load [37] and TG concentration which was not confirmed by our study. The reason for this may be the underestimation of dietary glycemic values due to the reluctance of patients to disclose to the dietician information on the consumption of non-recommended products abounding in simple sugars (sweets, sweetened drinks or sweeteners). The results of our study do not allow the hypothesis that the glycemic load of a diet affects TG concentration.
Physical activity is one of the key determinants of health [38]. It affects blood cholesterol levels [21], as noted in the study group. The recommended 30 minutes of activity a day was followed by only $1 / 4$ of the study patients. A higher proportion of patients in this group compared to the group with lower physical activity had normal HDL-C ( $47.4 \%$ vs. $39.3 \%)$ and TG $(62.3 \%$ vs. $52.6 \%)$. The benefits of physical activity were also presented by Silva et al. in the ELSA-Brasil Study, where moderate physical activity practice $\geq 150$ minutes a week was associated with increased HDL-C and decreased TG level means by $0.98 \mathrm{mg} /$ $\mathrm{dl}$ and $1.05 \mathrm{mg} / \mathrm{dl}$ respectively [39].

Calculations on the Framingham scale reported high cardiovascular risk in $3.75 \%$ and medium $12.5 \%$ of study patients. This represented almost of the examined group. Almost $60 \%$ of patients smoked cigarettes, which drastically increases cardiovascular risk [40]. In the study group smoking was the critical factor influencing the high CVD risk. Next were total and HDL-C. Studies have shown a positive correlation between the ratio of $\mathrm{n} 6 / \mathrm{n} 3$ and cardiovascular risk. This dependence was also described by Harris [41].

We found no correlation between the amount of SFA, MUFA and PUFA and cardiovascular risk. This allows for a partial acceptance of the validity of the research hypothesis. However, it is important to note that relatively young age was a protective factor in the study group. Therefore it can be expected that with the aging of the patients and no change in the eating habits that aggravate lipid disorders over time the cardiovascular risk will increase. According to the National Health and Nutrition Examination Surveys (NHANES) 1990-2004 the prevalence of metabolic abnormalities increased with age [42]. A similar finding was seen among the Canadian population where Setayeshgar et al. found that age was one of the strongest factors aggravating the risk of CVD [43].

\section{Conclusions}

The diet of the study group of $\mathrm{HIV}(+)$ patients should be properly balanced and requires modifications of many nutritional habits. Despite the use of antiretroviral drugs that have a negative effect on the lipid profile, improper diet seems to be a factor in the deterioration of its parameters.

The most important goal of lowering cardiovascular risk calculated with the Framingham scale would be to raise awareness and induce patients to quit smoking, to consider dietary intervention that emphasizes the quality of dietary fats that influence lipid profile and focus on a more active lifestyle in order to complete the scheme of non-pharmacological treatment to improve lipid management.

The effectiveness of treatment of HIV-infected patients may be strongly influenced by dietary intervention. Therefore it seems advisable to include a dietitian in the group of specialists who take care of these patients. Dietary support should be offered even to those patients whose cardiovascular risk is low, as it will increase with aging. 


\section{Acknowledgements}

We would like to thank Dr. Jacek Gąsiorowski for his kindness and support of the research and the head of the Dietetics Department of the Medical University in Wroclaw, Professor B. Regulska-Ilow, for the courtesy and availability of a diet analysis program.

\section{Conflict of interest}

The authors declare no potential conflicts of interest with respect to the research, authorship, and/or publication of this article.

\section{References}

1. Flisiak R, Wiercińska-Drapało A, Bociąga-Jasik M, et al. Metabolic abnormalities and cardiovascular risk in HIV-infected cohort of patients treated with protease inhibitors. HIV AIDS Rev 2015; 14: 22-27.

2. Palella FJ Jr, Delaney KM, Moorman AC, et al. Declining morbidity and mortality among patients with advanced human immunodeficiency virus infection. N Engl J Med 1998; 338: 853-860.

3. Parczewski M, Leszczyszyn-Pynka M, Boroń-Kaczmarska A, et al. Genetic background of the cardiovascular complications among HIV positive patients - preliminary report. HIV AIDS Rev 2007; 6: 28-31.

4. Leszczyszyn-Pynka M, Pynka S. Prevention of cardiovascular diseases in HIV-infected patients. HIV AIDS Rev 2006; 5: 28-30.

5. Shepherd J, Blauw GJ, Murph MB, et al. Heart Protection Study Collaborative Group. MRC/BHF Heart Protection Study of cholesterol lowering with simvastatin in 20,536 high-risk individuals: a randomized placebo-controlled trial. Lancet 2002; 360: 7-22.

6. Dube MP, Stein JH, Aberg JA, et al. Guidelines for the evaluation and management of dyslipidemia in human immunodeficiency virus (HIV)-infected adults receiving antiretroviral therapy: recommendations of the HIV Medical Association of the Infectious Disease Society of America and the Adult AIDS Clinical Trials Group. Clin Infect Dis 2003; 37: 613-627.

7. Kwiatkowska W, Bogdański P, Pulik P, et al. Postępowanie profilaktyczne, diagnostyczne i lecznicze w chorobach układu sercowo-naczyniowego u osób zakażonych HIV. In: Horban A, Podlasin R, Cholewińska G, et al. (eds.). Zasady opieki nad osobami zakażonymi HIV. Zalecenia PTN AIDS, Warszawa-Wrocław 2017, pp. 386-394.

8. Kłosiewicz-Latoszek L, Cybulska B. Zaburzenia lipidowe. In: Jarosz M. Praktyczny podręcznik dietetyki. IŻŻ, Warszawa 2010 , pp. 323-341.

9. High serum cholesterol and high CHD mortality. Available at: http://www.sevencountriesstudy.com/serum-cholesterol-and-coronary-heart-disease/ (Accessed: 20.03.2018).

10. Cross-cultural correlations (2018, March 20). Available at: http:// www.sevencountriesstudy.com/study-findings/cross-cultural/ (Accessed: 20.03.2018).

11. Mensink RP, Zock PL, Kester AD, et al. Effects of dietary fatty acids and carbohydrate on ratio of serum total to HDL cholesterol and on serum lipids and apolipoproteins: a meta-analysis of 60 controlled trials. Am J Clin Nutr 2003; 77: 1146-1155.

12. Howard BV, Hannah JS, Heiser CC, et al. Polyunsaturated fatty acids result in greater cholesterol lowering and less triacylglycerol elevation than do monounsaturated fatty acids in a dose-response comparison in a multiracial study group. Am J Clin Nutr 1995; 62: 392-402.

13. Simopoulos AP. The importance of the omega-6/omega-3 fatty acid ratio in cardiovascular disease and other chronic diseases. Exp Biol Med 2008; 233: 674-688.
14. Tzima N, Pitsavos C, Panagiotakos DB, et al. Mediterranean diet and insulin sensitivity, lipid profile and blood pressure levels, in overweight and obese people: The Attica study. Lipids Health Dis 2007; 6: 22.

15. Vasandi C, Kafrouni AI, Caronna A, et al. Upregulation of hepatic LDL transport by n-3 fatty acids in LDL receptor knock out mice. J Lipid Res 2002; 43: 772-784.

16. Cichocka A. Dieta śródziemnomorska w profilaktyce pierwotnej choroby niedokrwiennej serca. Endokrynologia, Otyłość i Zaburzenia Przemiany Materii 2005; 1: 30-39.

17. Wolańska D, Kłosiewicz-Latoszek L. Struktura spożycia kwasów tłuszczowych a profil lipidowy u osób z nadwagą i otyłością. Rocz PZH 2012; 63: 155-162.

18. Langsted A, Freiberg JJ, Nordestgaard BG. Fasting and nonfasting lipid levels: influence of normal food intake on lipids, lipoproteins, apolipoproteins, and cardiovascular risk prediction. Circulation 2008; 118: 2047-2056.

19. Roszkowski W, Chmara-Pawlińska R. Somatometria osób starszych jako wskaźnik stanu odżywienia. Roczn PZH 2003; 54: 399-408.

20. Perk J, De Backer G, Gohlke H, et al. European Guidelines on cardiovascular disease prevention in clinical practice (version 2012). The Fifth Joint Task Force of the European Society of Cardiology and Other Societies on Cardiovascular Disease Prevention in Clinical Practice (constituted by representatives of nine societies and by invited experts). Eur Heart J 2012; 33: 1635-1701.

21. Wilson PWF, D'Agostino RB, Levy D, et al. Prediction of coronary heart disease using risk factor categories. Circulation 1998; 97: 1837-1847.

22. Ford ES, Giles WH, Mokdad AH. The distribution of 10 -Year risk for coronary heart disease among US adults: findings from the $\mathrm{Na}$ tional Health and Nutrition Examination Survey III. J Am Coll Cardiol 2004; 43: 1791-1796.

23. ESHA. The Food Processor Nutrition Analysis Software. Available at: http://www.esha.com/products/food-processor-nutrition-analysissoftware/ (Accessed: 20.03.2018).

24. Bawadi H, Banks A, Tayyem R, et al. Meals served to hypertensive and cardiac inpatients in Jordan: comparison with WHO and $\mathrm{NIH}$ dietary guidelines. East Mediterr Health J 2016; 22: 27-32.

25. Jarosz M. Normy żywienia dla populacji polskiej - nowelizacja. IŻŻ, Warszawa 2012.

26. Nutrient requirements for people living with HIV/AIDS: report of a technical consultation. WHO, Geneva 2003.

27. Andersen L, Anderssen S, Bachl N, et al. Wytyczne UE dotyczące aktywności ficzycznej. Brussels 2008.

28. Tsiodras S, Mantzoros C, Hammer S, et al. Effects of protease inhibitors on hyperglycemia, hyperlipidemia, and lipodystrophy: a 5-year cohort study. Arch Intern Med 2000; 160: 2050-2056.

29. Lichtenstein AH, Appel LJ, Brands M. Diet and lifestyle recommendations revision 2006: a scientific statement from the American Heart Association Nutrition Committee. Circulation 2006; 114: 82-96.

30. AHA. The Facts on Fats 50 Years of American Heart Association Dietary Fats Recommendations, 2015. Available at: http://www. heart.org/idc/groups/heart-public/@wcm/@fc/documents/downloadable/ucm_475005.pdf (Accessed: 20.03.2018).

31. Fernandez ML, West K. Mechanisms by which Dietary Fatty Acids Modulate Plasma Lipids. J Nutr 2005; 135: 2075-2078.

32. Kłosiewicz-Latoszek L, Cybulska B. Choroby metaboliczne. In: Jarosz M (ed.). Praktyczny Podręcznik Dietetyki. IŻŻ, Warszawa 2010.

33. Mathews M, Liebenberg L, Mathews E. How do high glycemic load diets influence coronary heart disease? Nutr Metab 2015; 12: 6.

34. Li H, Liu H, Chen J, et al. Relationship between glycemic load and blood lipid level in hospitalized adult Chinese. Iran J Public Health 2015; 44: 318-324 
35. Leviatan B, Cook N, Stampfer M, et al. Dietary glycemic index, dietary glycemic load, blood lipids, and C-reactive protein. Metabolism 2008; 57: 437-443.

36. Venn BJ, Green TJ. Glycemic index and glycemic load: measurement issues and their effect on diet-disease relationships. Eur J Clin Nutr 2007; 61 Suppl 1: S122-131.

37. Finley CE, Barlow C, Halton T, et al. Glycemic index, glycemic load, and prevalence of the metabolic syndrome in the cooper center longitudinal study. J Am Diet Assoc 2010; 110: 1820-1829.

38. Physical Activity Guidelines for Americans. U.S. Department of Health and Human Services, Washington 2008.

39. Silva RC, Diniz Mde F, Alvim S, et al. Physical Activity and Lipid Profile in the ELSA-Brasil Study. Arq Bras Cardiol 2016; 107: 10-19.

40. Hard Coronary Heart Disease (10-year risk), 2017. Available at: https://www.framinghamheartstudy.org/risk-functions/coronary -heart-disease/10-year-risk.php (Accessed: 20.03.2018).

41. Harris WS. The omega-6/omega-3 ratio and cardiovascular disease risk: uses and abuses. Curr Atheroscler Rep 2006; 8: 453-459.

42. Wildman RP, Muntner P, Reynolds K, et al. The obese without cardiometabolic risk factor clustering and the normal weight with cardiometabolic risk factor clustering: Prevalence and correlates of 2 phenotypes among the US population (NHANES 1999-2004). Arch Intern Med 2008; 168: 1617-1624.

43. Setayeshgar S, Whiting SJ, Vatanparast H. Prevalence of 10-Year Risk of Cardiovascular Diseases and Associated Risks in Canadian Adults: The Contribution of Cardiometabolic Risk Assessment Introduction. Int J Hypertens 2013; 2013: 276564. 